\title{
The Genus Dracocephalum L. in the Phytogeographical Regions of Uzbekistan
}

\author{
Nilufar S. Abdullaeva1, Olimjon K. Khodzhimatov², Dilnoz E. Azimova1 \\ ${ }^{1}$ Djizak State Pedagogical Institute, Djizak, Uzbekistan \\ ${ }^{2}$ Institute of Botany Academy Sciences Republic of Uzbekistan, Tashkent, Uzbekistan \\ Email: ozodbek88@bk.ru
}

How to cite this paper: Abdullaeva, N.S. Khodzhimatov, O.K. and Azimova, D.E. (2019) The Genus Dracocephalum L. in the Phytogeographical Regions of Uzbekistan. American Journal of Plant Sciences, 10, 1527-1535.

https://doi.org/10.4236/ajps.2019.109108

Received: July 29, 2019

Accepted: September 7, 2019

Published: September 10, 2019

Copyright (c) 2019 by author(s) and Scientific Research Publishing Inc. This work is licensed under the Creative Commons Attribution International License (CC BY 4.0).

http://creativecommons.org/licenses/by/4.0/

\begin{abstract}
The article provides an analysis of the distribution of fourteen species belonging to seven sections of the genus Dracocephalum in the phytogeographical regions of Uzbekistan.
\end{abstract}

\section{Keywords}

Dracocephalum, Flora, Uzbekistan, Distribution, Phytogeographical Regions

\section{Introduction}

Dracocephalum L. is the second largest genus in the subtribe Nepetinae, tribe Mentheae of Lamiaceae family [1] because it is one of the largest and most complex genera of flowering plants. The genus is primarily of the Old World and consists of 71 species worldwide, of which 69 species are native to Eurasia [2] [3] [4] and North Africa and North America have one species each. The centre of distribution is presumably the alpine steppes of the Pamir Altay and Tian-Shan [5].

In general, representatives of the genus Dracocephalum L. are widespread in America, Asia and Europe. The greatest diversity of species of dragonhead is characterized in Siberia (24 species) and Central Asia (26 species). There are 26 species on the territory of Central Asia [2] [6], which occur in meadows, on rocky areas, in forest glades, from medium to subalpine and alpine mountain belts and are annual or perennial herbaceous plants or subshrubs, growing to 15 to 90 centimeters tall. The genus dragonhead (Dracocephalum) is one of the original taxa of the flora of Uzbekistan in the rank of the family Lamiaceae Lindl. In the flora of Uzbekistan, dragonhead is represented by fourteen species, which are mainly distributed in the northeastern and southeastern parts of the country, 
belonging to the Central Asian Mountain phytogeographical region, at the maximum altitudes (up to $3300 \mathrm{~m}$ ).

The complete Dracocephalum diversity of Middle Asia mountains geographical region (including Uzbekistan) is still unknown, as no extensive study on Dracocephalum species has so far been conducted in this area, which is biogeographically linked with Tajikistan, Kyrgyzstan and Kazakhstan. Therefore, an extensive field survey of Dracocephalum in the region was carried out to know the diversity and distribution of the species so that conservation and management practices could be initiated.

Among 14 species of Dracocephalum which growing in Uzbekistan, 1 species is endemic. The species of dragonhead $D$. adylovii Maltzev, $D$. nutans L. and $D$. imberbe Bunge grow on dry stony-shrubs and open slopes, sandy sediments, pebbles, go into the high mountains, where it occurs on Alpine and subalpine meadows.

On rocky outcrops inhabit: $D$. discolor Bunge, $D$. scrobiculatum Regél, $D$. oblongifolium Regél; on the slopes of mountain ranges grow: $D$. formosum Gontsch, $D$. integrifolium Bunge and D. spinulosum Pop. Alpine species: D. komarovii Lipsky, D. nodulosum Rupr., D. karataviense N. Pavl. \& Rold with the lower limit of distribution approximately $2600 \mathrm{~m}$ above sea level forms rather dense and clean thickets on stony-rubble talus and under rocks. D. nuratavicum Adylov. and $D$. diversifolium Rupr. are found in the middle and lower parts of the mountain belt on talus, represented by clay and rubble.

\section{Materials and Methods}

An analysis of the geographical distribution and ecology of the genus Dracocephalum species which are represented in Uzbekistan was carried out.

In the course of the research, analyses of information on this genus was observed in the nature and are herbarium materials stored in the National Herbarium fund of the Institute of Botany of the Academy of Sciences of the Republic of Uzbekistan (TASH), as well as the results of our own field research and collections. For a chorological analysis of the genus Dracocephalum L. of the flora of Uzbekistan, we have applied the system of geographical regionalization proposed by Tojibaev in 2016 (presented below on Figure 1). To clarify the distribution of species of the genus Dracocephalum in the botanical and geographical regions of Uzbekistan, we conducted route-based reconnaissance surveys of the Western Tien-Shan and Pamir-Alay ranges. Have been identified and described in natural populations of medicinal and aromatic species Dracocephalum, established their exact coordinates using a GPS-navigator.

\section{Results and Discussion}

According to the newest botanical and geographical regionalization (Tojibaev, 2016), the territory of Uzbekistan is divided between 2 floristic provinces: the Central Asian (Turkestan) and Turan (Aral-Caspian) provinces. A botanical and 


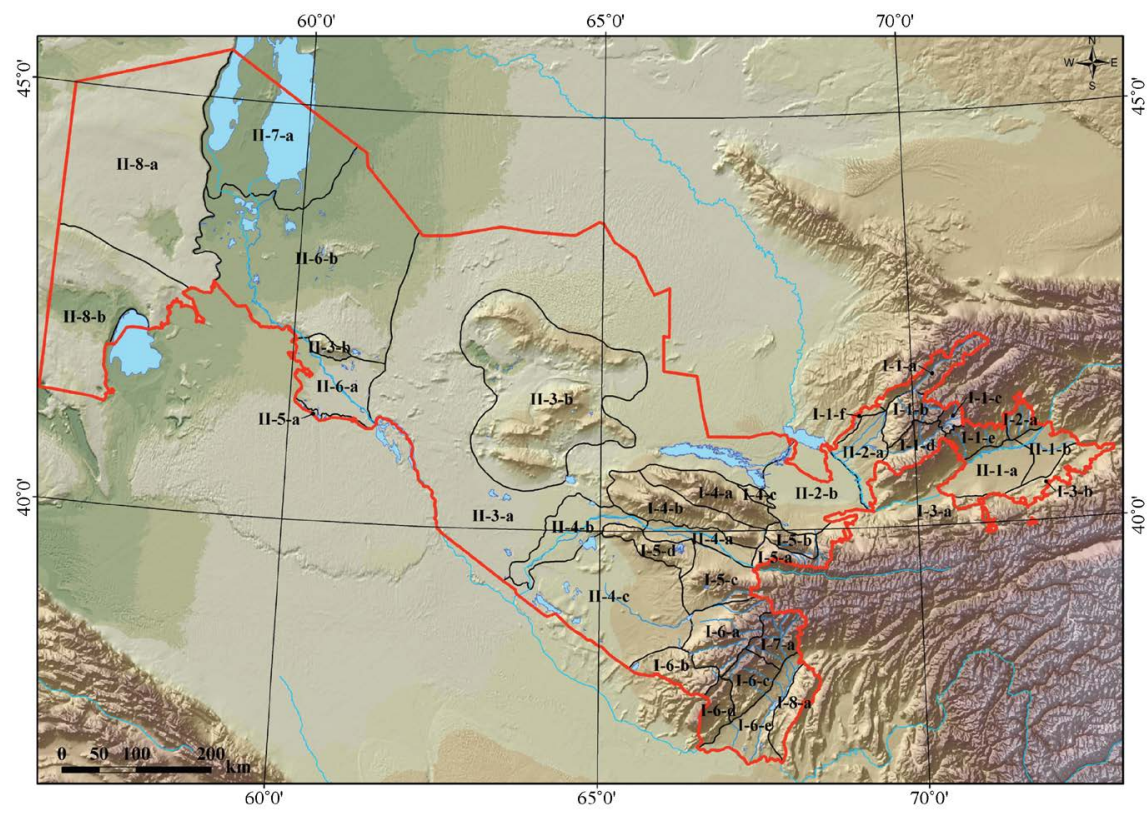

Figure 1. Phytogeographical division of Uzbekistan. I Central Asian Mountain Province: I-1 Western Tien Shan (I-1-a Ugam-Pskem, I-1-b Western Chatkal (Chimgan), I-1-c Arashan, I-1-d Kurama (Akhangaran), I-1-e Chorkesar, I-1-f Tashkent), I-2 Fergana (I-2-a South Chatkal), I-3 Fergana-Alay (I-3-a Western Alay, I-3-b Eastern Alay), I-4 Nuratau (I-4-a Nuratau, I-4-b Aktau, I-4-c Nuratau Relic Mountains), I-5 Kuhistan (I-5-a North Turkestan, I-5-b Malguzar, I-5-c Urgut, I-5-d Ziadin-Zirabulak), I-6 Western Hissar (I-6-a Kashkadarya, I-6-b Tarkapchigay, I-6-c Bayssun, I-6-d Kuhitang, I-6-e Surkhan-Sherabad), I-7 Hissar-Darvaz (I-7-a Sangardak-Tupalang), I-8 Panj (I-8-a Babatag). II Turan Province: II-1 Central Fergana (II-1-a Kayrakum-Yazyavan, II-1-b East Fergana), II-2 Middle-Syrdarya (II-2-a Chinaz, II-2-b Mirzachul), II-3 Kyzylkum (II-3-a Kyzylkum, II-3-b Kyzylkum Relic Mountains), II-4 Bukhara (II-4-a Middle Zeravschan, II-4-b Lower Zeravschan, II-4-c Karshi-Karnabchul), II-5 Karakum (II-5-a North-East Karakum), II-6 South Aral (II-6-a Khorezm, II-6-b Amudarya Delta), II-7 Aral (II-7-a Aral Sea Bottom), II-8 Ustyurt (II-8-a North Ustyurt, II-8-b South Ustyurt).

geographical analysis of mountain areas, based on the study of the structural and dynamic units of vegetation cover, makes it possible to approach the solution of many scientific and practical issues from the position of a systematic geographical approach. The test area is located within the Central Asian mountain region. For the mountains part of Uzbekistan, botanical and geographical region and 23 districts were allocated, in the lowland part-counties and 15 districts (Tojibaev, 2016).

The spectrum of geographical elements of the genus Dracocephalum is given below (Table 1, Table 2).

Consider in more detail the distribution of the species by botanical and geographical regions:

\section{I.1. Western Tien Shan region.}

I.1.a Ugam-Pskem district (9 species): D. adylovii I.I. Maltzev. in the river valley Pskem, on the rocks Maydantal ridge, river basin Tekeshsay, 05.05.2015, Tojibaev; on the rocks of the Kyzyltor-Beshtor watershed at 2420 meters above 
Table 1. The distribution spectrum of species of the genus Dracocephalum L. in the botanical and geographical regions of Uzbekistan.

\begin{tabular}{|c|c|c|c|c|}
\hline No. & $\begin{array}{l}\text { Botanical-geographical } \\
\text { regionalization }\end{array}$ & $\begin{array}{c}\text { Number of } \\
\text { endemic species }\end{array}$ & $\begin{array}{c}\text { Number of species } \\
\text { (within Uzbekistan) } \\
15 \text { species }\end{array}$ & $\%$ \\
\hline \multicolumn{3}{|c|}{ I.1. Western Tien Shan county } & 9 & 60 \\
\hline I.1.a & Ugam-Pskem & 1 & 9 & 60 \\
\hline I.1.b & Western Chatkal (Chimgan) & 2 & 9 & 60 \\
\hline I.1.c & Arashan (Angren plateau) & 2 & 7 & 46.6 \\
\hline I.1.d & Kurama (Akhangaran) & - & 4 & 26.6 \\
\hline I.1.e & Chorkesar & - & 5 & 33.3 \\
\hline \multicolumn{3}{|c|}{ I.2. Fergana-Alay gerion } & 5 & 43.7 \\
\hline I.2.a & Western Alay & - & 5 & 33.3 \\
\hline \multicolumn{3}{|c|}{ I.3. Nuratau region } & 1 & 12.5 \\
\hline I.3.a & Nuratau & 1 & 1 & 6.6 \\
\hline I.3.b & Aktau & 1 & 1 & 6.6 \\
\hline \multicolumn{3}{|c|}{ I.4. Kuhistan region } & 3 & 25 \\
\hline I.4.a & Northern Turkestan & - & 3 & 20 \\
\hline \multicolumn{3}{|c|}{ I.5. Western Hissar region } & 4 & 37.5 \\
\hline I.5.a & Kashkadarya & 1 & 4 & 26.6 \\
\hline 1.5.b & Baysun & - & 1 & 6.6 \\
\hline \multicolumn{3}{|c|}{ I.6. Hissar-Darvaz county } & 2 & 18.7 \\
\hline I.6.a & Sangardak-Tupalang & - & 2 & 13.3 \\
\hline
\end{tabular}

Table 2. The distribution spectrum of species of the genus Dracocephalum L. in the botanical and geographical districts of Uzbekistan.

\begin{tabular}{|c|c|c|c|c|c|c|c|c|c|c|c|c|c|c|c|c|}
\hline & $\begin{array}{l}\text { Botanical- } \\
\text { geographical } \\
\text { districts }\end{array}$ & 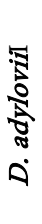 & 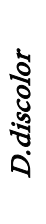 & 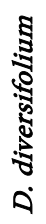 & 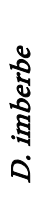 & 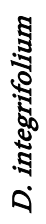 & 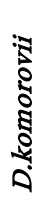 & 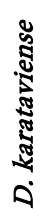 & 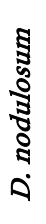 & 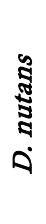 & 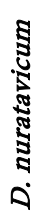 & 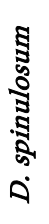 & 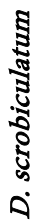 & 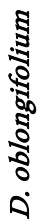 & 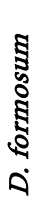 & 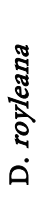 \\
\hline 1 & Ugam-Pskem & + & + & - & + & + & + & - & + & + & - & + & - & + & - & - \\
\hline 2 & Western Chatkal & - & + & + & - & + & + & + & + & + & - & + & - & + & - & + \\
\hline 3 & Arashan & - & + & - & - & + & + & + & + & + & - & - & - & + & - & - \\
\hline 4 & Kurama & - & + & - & - & - & - & - & + & + & - & - & - & + & - & + \\
\hline 5 & Chorkesar & - & + & - & - & + & - & - & + & + & - & - & - & + & - & - \\
\hline 6 & Western Alay & - & + & + & + & + & - & - & - & - & - & - & - & + & - & + \\
\hline 7 & Nuratau & - & - & - & - & - & - & - & - & - & + & - & - & - & - & + \\
\hline 8 & Aktau & - & - & - & - & - & - & - & - & - & + & - & - & - & - & + \\
\hline 9 & $\begin{array}{l}\text { Northern } \\
\text { Turkestan }\end{array}$ & - & + & + & - & - & - & - & - & - & - & - & + & - & - & + \\
\hline 10 & Kashkadarya & - & + & - & - & + & - & - & - & - & - & - & + & - & + & + \\
\hline 11 & Baysun & - & - & - & - & - & - & - & - & - & - & - & - & - & + & + \\
\hline 12 & $\begin{array}{c}\text { Sangardak- } \\
\text { Tupalang }\end{array}$ & - & - & - & - & - & - & - & - & - & - & - & + & - & + & + \\
\hline
\end{tabular}


sea level, Pskem Ridge, Oygaing, Beshtor, 25.07.2011, Maltsev, D. discolor, D. imberbe, D. integrifolium Pskem, Headwaters Oygaing, Tastarsay, 33,000 m. a.s.l. 17.07.2002, Maltsev, Tojibaev; 06.06.1950, Korotkova; D. komarovii, D. nodulosum, $D$. nutans, $D$. oblongifolium river valley Pskem, Maydantal uch, river basin Tekeshsay, 02.08.2015, Tojibaev, Pskem, Machitasgan-say on the rocks, 07.26.2018, Abdullayev, Pskem, Ainatash, 07.26.2018, Abdullayev, D. spinulosum Ugam ridge, river basin Pskem, Pskemsay, 2012.28.07, Maltsev, Pskem, Machitasgan-say, on the rocks, 07.26.2018, Abdullayev, Pskem ridge, Ainatash, 07.26.2018, Abdullayev, Ugam ridge Kuromjol Say, 07.28.2018, Abdullayev. One species-D. adylovii is endemic to the region.

I.1.b Western Chatkal (Chimgan) district (9 species): D. discolor Chatkal ridge, Maydantal uch Adamtash, 07.09.1959, Petrov, D. diversifolium Chatkal Biosphere Reserve area Bashkzylsay, Kyzylnura, 06.29.2001, Tojibaev, Maltsev; $D$. nodulosum, $D$. nutans on gravelly, stony slopes, on scree, in the crevices of rocks, among boulders, from plains to the upper mountain belt. $D$. oblongifolium Big Chimgan, in the direction of the sandy pass, 1926, Baranov, Raikova; Chatkal ridge, Tashkeskensay headwater below a glacier and two lakes, on the rocks., 08.08.1977, Levichev, Krasovskaya; Maidantal, watershed Tashkeskensay and Kelencheksay, 08.11.2013, Beshko. D. spinulosum river bank Chimgan, 07.29.1925, Korovin; neighborhood Chimgan Bot. station, Big Chimgan, 08.16.1927, Gomolitsky, headwaters Kok-su, 10.09.1928, Kultiasov; Chatkal mountain forestry reserve, Maydantal, AkTahtay mountains, 07.11.1980. Levichev, Krasovskaya; D. karataviense Chatkal mountain-forestry reserve, Maydantal, Zindon-say, on pebble, above the field base, 08.03.1977. Krasovskaya; pass Maydantal upper course Chadaksay, 2330 m. 24.06.1991, Maltsev. D. integrifolium, D. komorovii Parkentsai, Kyzylnura, 2800 m a.s.l., 20.08.1988, Maltsev.

I.1.c Arashan (Angren plateau) (7): D. discolor-saddle at the pass Arashan, 08.31.1940, Pyataev, lake Arashan, 3100 m a.s.l., 1993, Maltsev, right side of the lake Arashan, on the rocks, 08.11.2018, Abdullayev. $D$. integrifolium, $D$. komorovii-lake Arashan, Tulpar-Kul, 08.11.2018, Abdullayev. D. nodulosum on stony and gravelly mountain slopes, on scree and on rocks in the middle and upper belt of mountains on the height, up to $3300 \mathrm{~m}$ a.s.l. D. nutans, D. oblongifolium, D. karataviense-shore of the upper at the lake Arashan, $2830 \mathrm{~m}$ a.s.l., 07.27.1993, Maltsev, of the upper Koytashsay, above the lake Arashan, 02.08. 1993, Maltsev, Angren-Plateau, headwaters of the Say Koytash, $3300 \mathrm{~m}$ a.s.l., 02.08.1993, Maltsev.

I.1.d Kurama (Akhangaran) (4): D. discolor on stony and gravelly rocks, on alluvial deposits, on moraines in the upper mountain belt, $D$. nodulosum, $D$. nutans, $D$. oblongifolium.

I.1.e Chorkesar district (5); $D$. discolor, $D$. integrifolium, $D$. nodulosum, D. nutans, D. oblongifolium-Fergana Valley, river Rizaksay, left bank of the river, 07.06.2015, Tojibaev, Naralieva. 


\section{I.2. Fergana-Alay region.}

I.2.a Eastern Alay district (5): D. integrifolium, D. imberbe, D. oblongifolium, $D$. discolor, $D$. diversifolium river basin Shakhimardan neighbourhood vill. Yardan river valley Dugoba-say, 06.30.1961, Pyataev, north slope of the river basin Shakhimardan, headwaters of Yardan, Ikki-Airy, 1962.25.06, Tsukervanik.

\section{I.3. Nuratau region.}

I.3.a Nuratau ridge (1): D. nuratavicum Farish district, 05.06.1941, Momotov; Koy-tash mountains, 05.28.1941, Lepetkin; Dushak mountains, 1750 m a.s.l., 07.06.1994, Beshko; Khayat-say and Majerumsay watershed, 06.06.2011, Beshko; watershed Andibaraut and Alichak, 06.06.2018, Abdullayev.

I.3.b Aktau (1): D. nuratavicum Aktau, 06.12.1984, Shimolina.

Studies have shown that $D$. nuratavicum is found in the Nurata Mountains at an altitude of $1200-1300 \mathrm{~m}$ above sea level. The species can be found on flat surfaces, among shrubs on stony-rubbly soils, in plant-rich populations.

\section{I.4. Kuhistan region.}

I.4.a Northern Turkestan district (3): D. discolor pass Oburdan, S. slope near the top of 1928, Pikov, D. diversifolium river basin Guralash pass from Guralash to Kizil-turuk. 18.07.1934, Zakrzhevsky, Chumkar-tau mountains, upper flow of Baykungur S slope among juniper, 16.08.1932, Titov, Eliseeva; Kulsay juniper, N slope, 03.08.1954, Obonitskaya; Zaamin National Park Uryukli, trail, 31.05.2016, Maltsev, Zaamin National Park near Chortang, 26.06.2018, Abdullayev, Kulsay, left bank of the Tuyuk-Saya, 06.27.2018, Abdullayev, Kulsay, Sufa. 07.07.2018, Abdullayev, Baykungur, Kzyl-jar, 21.07.2018, Abdullayev. D. scrobiculatum is found on stony placers, near the glaciers in the upper mountain belt on the height. 2200 - 3800 m, gorge river Guralash, 21.07.1926, Popov, Androsov, Sanzar, W Guralash, 08.08.1937, Korotkova, Vasilkovskaya; river basin Zaamin-su, river Kul-say, Kyzyl-Mazar, 07.08.1960, Korotkova, Khamidhodzhaev, Zaamin National Park, Shivirlisay, 02.07.2018. Abdullayev.

\section{I.5. Western Hissar region.}

I.5.a Kashkadarya district (4): D. discolor mountains near Yakkabaga, 04.07.1927, Kultiasov, Granitov, pass to Tashkurgan, watershed, $3000 \mathrm{~m}$ a.s.l., 06.22.1988, Khasanov, $\boldsymbol{D}$. diversifolium upper river Igrisu neighborhood of the vill. Dukankhona, 07.20.1991, Korotkova; on the road between the villages of Cholmozar and Tashkurgan, 07.29.1948, Korotkova; vill. Gilan 2500 m 27.07.1988, Khasanov, river basin Tankhazdarya, 15.07.1997; D. formosum o wet and damp places, near springs in the upper mountain belt, $2400-3000 \mathrm{~m}$ a.s.l. Neighbourhood of the vill. Tashkurgan Kapyr-say, 06.06.1936, Bochantsev; river basin Kyzyl-su, near the Kyzylgaz pass, 2524 meters a.s.l., 12.07.2013, Beshko; Tashkurgan village, Temur cave, 07.15.1997, Maltsev. D. scrobiculatum Shahrisabs, neighborhood of the vill. Tashkurgan, Pyr-Pyr Mountain, 07.07.1936, Budantsev, upper river Aksu, the foot of the Khazret-Sultan mountain, 07.21.1997, Maltsev, lake Djanka, 07.28.1985, Maltsev.

I.5.b Baysun district (1): D. formosum Sary-Assiy district near Kaynar-Bulak, 17.07.1932, Taraevich. 


\section{I.6. Hissar-Darvaz region.}

I.6.a Sangardak-Tupalang district (2); $D$. formosum river basin Tupalang, river valley Chash, 06.20.1948, Pyataeva; D. scrobiculatum river basin Ak-su, upper river Tamshush, town Khodzhagulvars, 08.06.1941, Povarov, Chulbair Mountains, at the spring near the foot of Khoja-Bark, 17.07.1943, Vvedensky.

Comparative analysis of the distribution of the genus Dracocephalum species by botanical and geographical regions with the calculation of the Jacquard coefficient (Table 3 ) is on the basis of which clusters of similarities between regions were constructed.

For a comparative description of the regions of Uzbekistan, a comparative analysis of the floristic complexes of the inner regions was carried out with the calculation of the Jacquard coefficient (Table 3). Based on the data obtained, the similarity between the areas was processed using the Past 3.14 program (Figure 2).

According to the cluster analysis, the genus Dracocephalum L., the similarity of the botanical and geographical regions of Uzbekistan within Northern Turkestan (13) was divided into two large areas: North Turkestan (14); Ii. Kurama (4).

A group of Northern Turkestan regions: North Turkestan, Malguzar, Kashkadarya, Sangardak-Tupalang, Tarkapchigay, Baisun, Kugitang, Nurata, Aktau, Nurata outliers, Ziyaudin-Zirabulak, Tashkent.

Group of Kuraminsky district: Western Chatkal, Ugam-Pskem, South Chatkal, Arashan, Chorkesar, West Alay, East Alay.

Each of the two groups of botanical regions mentioned above is different from the proximity of species and their interconnectedness.

Thus, the distribution of the species Dracocephalum L. in the botanical and geographical regions of Uzbekistan is divided into two separate groups (Figure 2).

Table 3. The value of the Jacquard coefficient for the compared botanical-geographical regions of Uzbekistan.

\begin{tabular}{ccccccccccccc}
\hline $\begin{array}{c}\text { Botanic-geographical } \\
\text { regions }\end{array}$ & $\mathbf{1}$ & $\mathbf{2}$ & $\mathbf{3}$ & $\mathbf{4}$ & $\mathbf{5}$ & $\mathbf{6}$ & $\mathbf{7}$ & $\mathbf{8}$ & $\mathbf{9}$ & $\mathbf{1 0}$ & $\mathbf{1 1}$ & $\mathbf{1 2}$ \\
\hline $\begin{array}{c}\text { Ugam-Pskem } \\
\text { Western Chatkal } \\
\text { Chimgan) }\end{array}$ & $\mathbf{0 . 5}$ & 0.43 & 0.4 & 0.30 & 0.35 & 0.30 & - & - & 0.1 & 0.18 & 0.18 & - \\
Arashan & 0.5 & 0.41 & 0.33 & 0.33 & 0.33 & 0.09 & 0.09 & 0.23 & 0.23 & 0.09 & 0.09 \\
Kurama & 0.44 & 0.5 & 0.44 & $\mathbf{0 . 5}$ & 0.44 & 0.37 & 0.16 & 0.16 & 0.28 & 0.28 & 0.16 & 0.16 \\
Chorkesar & 0.5 & 0.5 & 0.5 & 0.44 & $\mathbf{0 . 5}$ & 0.37 & - & - & 0.16 & 0.28 & - & \\
Western Alay & 0.4 & 0.4 & 0.33 & 0.4 & 0.33 & 0.5 & $\mathbf{0 . 1 4}$ & 0.14 & 0.33 & 0.33 & 0.14 & 0.14 \\
Nuratau & - & 0.33 & - & 0.33 & - & - & 0.5 & - & - & - & - & 0.33 \\
Aktau & - & - & - & - & - & - & - & 0.5 & - & 0.33 & - & 0.33 \\
Northern Turkestan & 0.2 & 0.42 & 0.33 & 0.2 & 0.2 & 0.42 & 0.2 & 0.2 & 0.5 & 0.42 & - & 0.2 \\
Kashkadarya & 0.28 & 0.44 & 0.28 & 0.28 & 0.28 & 0.28 & 0.16 & 0.16 & 0.37 & 0.5 & 0.28 & 0.16 \\
Baysun & - & - & - & - & - & - & - & - & - & - & 0.5 & 0.33 \\
Sangardak-Tupalang & - & - & - & - & - & - & - & - & 0.25 & 0.5 & 0.4 & 0.5 \\
\hline
\end{tabular}




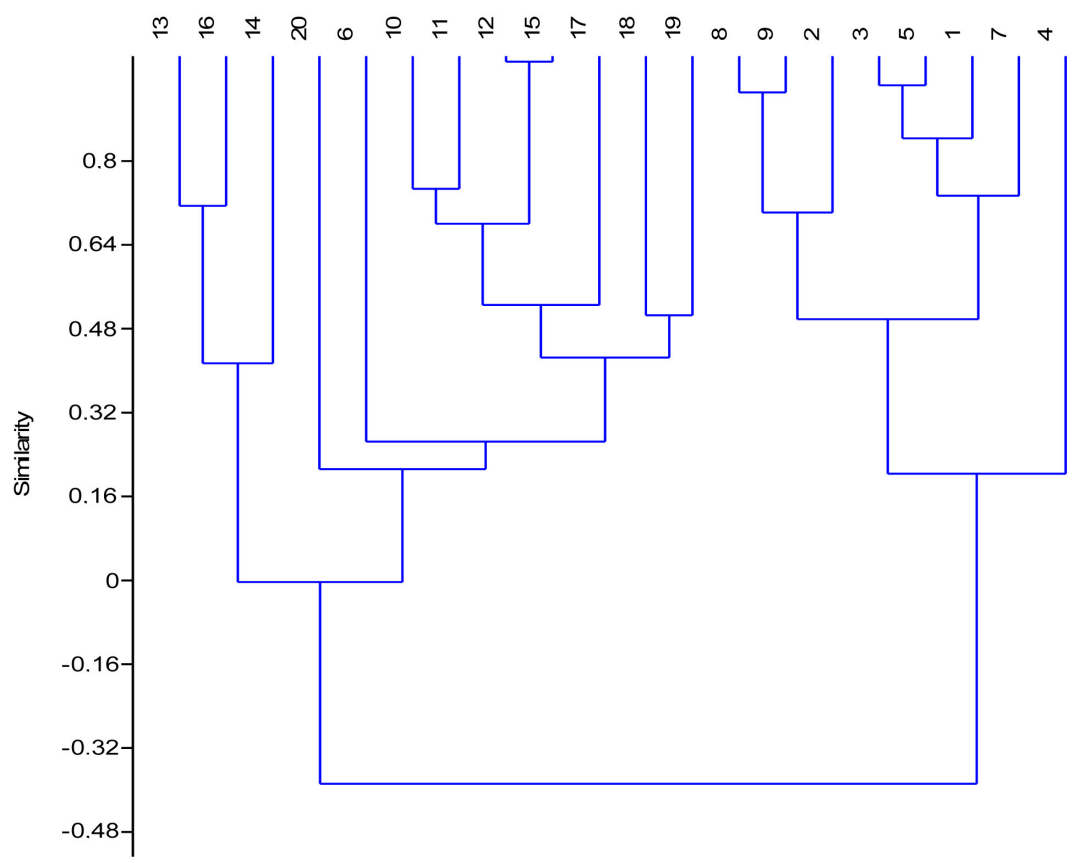

Figure 2. The cluster scheme for analyzing the genus Dracocephalum L. similarities in the botanical and geographical regions of Uzbekistan.

Based on the analysis of the distribution of Dracocephalum L. species in the botanical and geographical regions of Uzbekistan using their own herbarium material, herbarium specimens stored in the National Herbarium Fund (TASH), the distribution spectrum of species of this genus in the botanical and geographical regions of Uzbekistan showed that in the Tien Shan region-60\%, in Fergano-Alai district-50\%, in Gissar district-37.5\%; in the Kukhistan district-25\%, in the Fergana and Nurata regions- $-12.5 \%$, and in the rest of the regions- $6.2 \%$. These botanical and geographical districts occupy the territories of the mountainous districts of the Tashkent, Namangan, Fergana, Syrdarya, Djizak, Samarkand, Navoi, Kashkadarya and Surkhandarya regions of Uzbekistan. These species are common in the western Tien Shan, Fergano Alai and West Gissar in botanical and geographical regions. Relief, humidity and edaphic factors in these regions are sufficient for plant growth.

\section{Conclusion}

From the descriptions provided, it can be concluded that in the selected botanical and geographical regions, the main difference between regions is largely determined not by climatic factors, but is based on the relief features, lithological structure of landscapes, the prevailing soil types, the nature of the plant cover and, as a result, the presence of different species of the genus.

\section{Conflicts of Interest}

The authors declare no conflicts of interest regarding the publication of this paper. 


\section{References}

[1] Sonboli, A., Naderifar, M. and Dholipour, A. (2015) Pollen Morphology of Iranian Dracocephalum L. (Lamiaceae) and Its Taxonomic Significance. Bangladesh Journal of Plant Taxonomy, 22, 99-110.

[2] Budantsev, A.L. (1987) The System of the Genus Dracocephalum (Lamiaceae). Botanicheskii Zhurnal, 72, 260-267. (In Russian)

[3] Budantsev, A.L. (1993) A Synopsis of the Tribe Nepeteae (Lamiaceae)-the Genera Lophanthus, Dracocephalum, Cedronella, Schizonepeta and Agastache. Botanicheskii Zhurnal, 78, 106-115. (In Russian)

[4] Kaderiet, J.W. (2004) Flowering Plants: Dicotyledons, Lamiales (Except Acanthaceae including Avicenniaceae). In: Kubitzki, K., Ed., The Families and Genera of Vascular Plants, Springer-Verlag, Berlin.

[5] Diklić, N. (1999) Dracocephalum ruyschiana L. In: Stevanović, V., Ed., The Red Data Book of Flora of Serbia, University of Belgrade, Belgrade, 70-71, 416-417.

[6] Abdullaeva, H.S. and Khodzhimatov, O.K. (2016) Dracocephalum L. Genus (Lamiaceae) in Uzbekistan's Flora. Bulletin of Bryansk Department of Russian Botanical Society, 2, 3-8. 